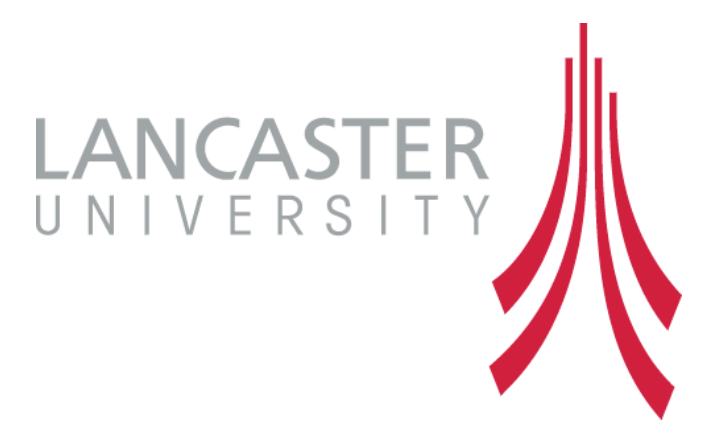

\title{
Consumption caught in the 'cash nexus'
}

\section{Tim Dant}

The final version of this paper was published in Sociology, 2000, Vol 34 (4): 655-670, ISSN 0967-5507

Please quote and cite the published version.

Department of Sociology

Bowland North

Lancaster University

Lancaster, LA1 4YT

t.dant@lancaster.ac.uk

01524593184 


\section{Consumption caught in the 'cash nexus'}

\section{Abstract}

During the last thirty years, 'consumption' has become a major topic in the study of contemporary culture within anthropology, psychology and sociology. For many authors it has become central to understanding the nature of material culture in the modern world but this paper argues that the concept is, in British writing at least, too concerned with its economic origins in the selling and buying of consumer goods or commodities. It is argued that to understand material culture as determined through the monetary exchange for things - the cash nexus - leads to an inadequate sociological understanding of the social relations with objects. The work of Jean Baudrillard is used both to critique the concept of consumption as it leads to a focus on advertising, choice, money and shopping and to point to a more sociologically adequate approach to material culture that explores objects in a system of models and series, ‘atmosphere', functionality, biography, interaction and mediation.

Keywords: consumption, material culture, Baudrillard, cash nexus, quasisocial

Word length: 5840 for text and endnotes (6946 including title page, biography, abstract, and bibliography) 


\section{Introduction}

The topic of 'consumption' has become, particularly within the fields of sociology (Campbell 1987; Bocock 1993; Slater 1997; Corrigan 1997; Lury 1997; Miles 1998), psychology (Lunt and Livingstone 1992; Dittmar 1992) and anthropology, (Isherwood and Douglas 1979: Appadurai 1986: McCracken 1990, Miller 1987; 1995; 1998) a key way of thinking about contemporary cultures and in particular the material culture of modern societies. But the way that 'consumption' tends to be understood is, I wish to suggest, all too often concerned with the social features of the economic process of exchanging cash for goods or commodities - what I am going to call the 'cash nexus'. The idea of consumption tends to treat the complexity of social relationships that constitute material culture as consequent on the key social action of buying and selling. I will argue that material culture is best understood as realised through the 'quasi-social' relationships that people have with objects relationships to do with the meanings of, and interaction with, the object that are not determined by the cash nexus.

In this paper I want to argue that a focus of attention has shifted from the sphere of production, that was at the centre of concern in the United Kingdom of the 1970s, to the sphere of consumption. Just as the discussion of that time about the affluence of workers and the relations of production became impacted around the issue of cash payments to labour so the discussion of consumption and relationships between the material things people appropriate into their lives has recently become impacted around the payment of cash for commodities. 


\section{The affluent society}

The discussion of consumption, within sociology at least, has grown out of the attempt to grasp the nature of what J.K. Galbraith famously called the 'affluent society' (1962 [1958]). He argued that the social and economic organisation of modern societies needed to leave behind the myth of the centrality of production together with a set of ideas about needs and wants that derived from the experience of poverty and insufficiency. In its place he argued for the importance of the creation and management of consumer demand, providing a brutalist vision of political economy in which the forces of the market indicated the moral as well as the economic order: "No tears should be wasted on the farmers who go bankrupt. This is the path to more efficient farm production" (Galbraith 1958: 235). The response of sociology was of course more cautious, recognising that the moral order could not so easily be understood by appeal to abstractions such as efficiency. Galbraith was articulating the economic forces that operated in the affluent society but he had little to say about the feelings, attitudes, relationships, sense of identity, groupings or everyday lives of the people in that society. Nonetheless, his argument that attention needed to be shifted from the field of production to that of consumption was compelling.

If Galbraith's argument was about the management of demand, the sociological response, especially in a very fertile period of sociology in the United Kingdom, was to consider what happens to the worker in the affluent society. The attitudes and responses of the worker were not simply economic; they were also political and social. While the power of the worker could be seen to be diminishing in terms of influencing the process of production, the 
affluence of the worker became crucial to the sustaining of demand. The affluent society depended on the influence of the producers over the needs and wants - material, economic, social and political - of the worker:

Most goods serve needs that are discovered to the individual not by the palpable discomfort that accompanies deprivation, but by some psychic response to their possession. They give him (sic) a sense of personal achievement, accord him (sic) a feeling of equality with his (sic) neighbors, divert his (sic) mind from thought, serve sexual aspiration, promise social acceptability, enhance his (sic) subjective feeling of health, well-being or orderly peristalsis, contribute by conventional canons to personal beauty, or are otherwise psychologically rewarding.

(Galbraith 1967: 201)

For Galbraith and the 'ad-men' the problem was seen as psychological but the shift in orientation to production and consumption that he was describing would have dramatic effects on social structure; on social class, status, community and identity. It was the selling of goods that Galbraith saw as the dynamic of affluent society; the exchanging of cash for manufactured commodities. This cash nexus, I wish to argue, has become the dominant concern of the social sciences that address 'consumption' - the mechanics of selling determine the form of consumer society. But first I will comment on the critical history of the 'cash nexus'.

\section{The cash nexus}

I first came across Marx's use of the phrase the 'cash nexus' when, as an undergraduate, I read an article by John Westergaard, published in 1970 called "The Rediscovery of the Cash Nexus". For Westergaard and other Marxist commentators, the structure of contemporary society could be 
understood through a study of the dynamics of class formation and the relations of production. He identified in a number of studies ${ }^{1}$, most importantly the famous The Affluent Worker survey of Luton car workers, (Goldthorpe et al. 1968), a rediscovery of what Marx and Engels called in The Manifesto of the Communist Party, the 'nexus of cash payments'. In borrowing the phrase from Thomas Carlyle ${ }^{2}$, Marx and Engels were making the point that the albeit unequal - reciprocal obligations of feudal and patriarchal relations were replaced by the "naked self-interest" of "cash payments" in bourgeois, capitalist society (Marx and Engels 1968:38)

For Westergaard the capitalism of the 1950s and 1960s had produced an amorphous class of affluent, privatised and instrumental workers with no clear social or cultural form. The community oriented but fragmented working class of early industrial capitalism in which the worker was connected to the social structure through a commitment to work and to fellow workers, was replaced by the formal link of cash for labour. The cash nexus had become the "main bond that tied many people to the social order" (Westergaard and Resler 1975: 6) early in the development of capitalism and by the 1970s had become characteristic of the relations of production. The cash nexus was capitalism at work; rewarding labour for producing goods efficiently with increasingly high wages but no industrial or political power.

It was of course precisely in this climate of sociology that consumption began to be an issue - the increasing wages of some workers under capitalism needed to be spent somewhere and the mass-produced goods needed to be sold. The empirical studies and sociological analyses of the 'affluent society' and of the embourgeoisement of workers were beginning to describe social 
structure as formed not simply in the relations of production but also in the relations of consumption ${ }^{3}$.

In the same year as Westergaard's article appeared in English, in France Jean Baudrillard's La Société de Consommation was published. Although an English edition has only very recently been published $\left(1998\right.$ [1970]) ${ }^{4}$, I want to accuse Baudrillard with having put a version of consumption into the field of sociology that has a focus on the cash nexus. He specifically responds to Galbraith's concept of the affluent society to argue that it is better understood as a 'consumer society'. Baudrillard began to raise the issues of consumption in the final quarter of his earlier The System of Objects (1996 [1968]), but I want to use some of the ideas in the first three quarters of that book to begin to recover material culture beyond the cash nexus for sociological study. It seems quite appropriate in English to read Baudrillard backwards since his later work was translated before his earlier work!

In the remainder of this paper I will firstly explore what I mean by consumption at the cash nexus. Then I will suggest some alternative ways of approaching the material culture of modern societies. Thirdly I will reprise Baudrillard's consumption theory, by arguing that he is not studying consumption as a social practice but critiquing the form of consumer society.

\section{Consumption and the cash nexus}

My problem with consumption is not that it is not a proper concern for sociology or that it is dull or irrelevant. It is that the sociological study of material culture has emerged within theories and studies of consumption and because of this is organised around a group of topics that are directed primarily to the buying and selling of objects. The effect is that the social 
relations between human society and material things that constitute material culture appear to be determined by the cash nexus. Just as the cash nexus of the affluent worker studies that Westergaard criticised did not adequately account for changes in social and political structures, so the cash nexus in consumption is inadequate to understand the development of contemporary material culture.

As the topic of consumption was taken up in British sociology, there was a concern with its historical emergence and its relation to traditional modes of understanding modernity, especially those of Weber (Campbell 1987) and Marx (Bocock 1993). From the anthropological tradition however, attention focused on the connections between the economic notion of consumption as an exchange of goods and the consequent exchange of meanings which would constitute culture (Sahlins 1976; Douglas and Isherwood 1979). Miller brought the themes of modernity in Hegel, Marx and Simmel together with those of meaning and culture (1987). In articulating consumption as a central feature of contemporary cultures, this sociological and anthropological tradition also identified consumption as the social practice in which human relationships with material culture are established. Within this tradition the impact of consumption has been seen as linked to the shaping of 'postmodern culture' (Featherstone 1991) through an 'ideology of consumerism' (Bocock 1993) that has led to a consumerist 'way of life' (Miles 1998). These cool sociological accounts of how late modern society is, describe a social world dominated by the buying of goods and services but without the critical irony of Baudrillard's much earlier description of the consumer society. The British account of consumption does however share a set of concerns with 
Baudrillard that tie the analysis of consumption back into the economic concern with purchasing of goods - I will mention four.

The first and most pervasive theme is that of the image of the object; the concern with advertising, with the presentation of objects, their novelty, their distinctiveness (see e.g. McCracken 1990; Featherstone 1991; Corrigan 1997; Lury 1996; Slater 1996). Here the pressures to sell goods are often taken as equivalent to the goods themselves; advertisements are taken to be more adequate representations of the objects than the objects themselves. The meanings formed in advertisements by associations between things for sale and other things which already have cultural value is taken to be exchanged in the process of consumption. Baudrillard sets the pattern by sprinkling his argument not with traditional forms of sociological evidence but with quotations of the impacted, sub-poetic language of advertisements (1998).

Secondly, there is the key issue of choice (e.g. Lury 1997; Slater 1997) through which consumers demonstrate their taste and social standing. Through deciding when and if to part with cash and for which of a range of goods, individuals appear to be using a blend of knowledge, experience, imagination and fantasy to express personal choice, relatively independent of the determinants of the mode of production ${ }^{5}$. Of course the counter argument has been put from the beginning by a series of commentators (including Leiss 1978; Haug 1986; Jhally 1987; Ewen and Ewen 1992) that consumption is determined in large measure by the forces of production through processes such as advertising. However, it is not unreasonable to argue as Gabriel and Lang (1995) do that this case is grossly overstated; consumers are not 
infinitely available to be duped and manipulated and their identity cannot shaped or read-off from the commodities they choose.

Nonetheless, the possibility for voluntarily expressing identity with, for example, a youth sub-cultural group or a sophisticated fashionable clique through consumption, has attracted the attention of sociologists (e.g. Lury 1996: 192-225). Choice in consumption is, for some commentators (e.g. Miller 1995: 39-48), a quasi-political act in which the citizen expresses their approval or not of the actions of a range of social institutions. Again this theme is put into play in Baudrillard's discussion of personalisation, of the way commodities and advertisements hail the individual consumer, making them feel unique and distinct but simultaneously fitting them into a social structural niche of consumer categories (1998: 87-98).

Thirdly is money itself. It is at the end of The System of Objects that Baudrillard discusses 'credit'; buying the postponement of the cash nexus is a feature of consumer societies (1996: 156-163). He returns to the theme briefly in The Consumer Society (1998: 29, 81). Within the contemporary debate on consumption the issue of money has become linked to commerce (Slater 1997: 22), saving (Douglas and Isherwood 1979: 11-35), credit and credit cards (Lunt and Livingstone 1992: 192) and thrift (Miller 1998a: 49-62, 132137). Limited cash resources are distributed by consumers in particular ways that are taken to reflect their engagement with society. Bargain hunting is one of the ways that the significance of cash is experienced in the cash nexus of consumption. For Daniel Miller (1998a) looking for bargains is the modern form of ritual sacrifice, enacted daily in the routines of provisioning in the high street mini-market: 
... it is possible for shoppers to regard virtually the whole of the shopping expedition and the purchase of almost any specific item within that expedition, not as an act of spending at all, but as an act of saving.

(Miller 1998a: 56).

The fourth and increasingly central theme is the field of shopping itself, not only the activity of shopping but the scene of shopping; the mall, the department store, the home-shopping brochure and so on (e.g. Shields 1992; Corrigan 1997: 50-65; Falk and Campbell 1998; Miller et al. 1998b). Here it is the context that is taken for the object; it derives its meaning from the surroundings in which it is purchased and it in turn marks the identity of its purchaser. Baudrillard sets this topic in motion with his discussion of the 'drugstore' and the way that items are presented for sale; neither en masse nor systematically arranged as in the department store, but arrayed alongside each other, different classes and types of product, for different purchase at different times (Baudrillard 1996). This characteristically postmodern vision of order in decline, of what appears to be chaotically different in one glance being so much more of the same in the next, has given way to recoveries and analyses of all the myriad other contexts for doing shopping.

\section{Material culture}

My argument is not against the sociological study of consumption as such the themes of image, choice, money, and shopping context, have produced interesting and valuable work that needs to be put alongside the 1960s analyses of the situations of affluent workers. Moreover, I recognise that all the commentators on consumption I have mentioned are also interested to varying degrees with material culture. What I am arguing is that their account 
of material culture, the meanings and uses of objects, derives from their understanding of objects through the medium of the cash nexus. Consumption theorists seem to accept that the substantive relationship with objects begins and is in large measure determined by the management of want and the expression of choice realised when money is exchanged for goods during shopping.

I want to argue that there are other practices of living with objects that can be more important in understanding material culture than those that are associated with consumption as purchase. I will briefly mention a number of themes but, for a change of pace, will wind them into a short narrative ${ }^{6}$.

In my kitchen is a knife that I estimate to be twenty-seven years old - I came by it around the time Westergaard's article and Baudrillard's book were being published $^{7}$. A little while later I had an argument with the live-in girlfriend of the person I shared a flat with about who owned it. She maintained that the knife was given to her by her parents in Surrey and had been with her through university at Exeter, survived a relationship in Sussex and come with her to London. My story was that I remembered buying it in Reading from whence it had travelled with me to Stoke and later to Portsmouth and then on to London. Now I definitely remember buying a knife, but to be honest, I'm not now at all sure whether it was this knife. At the time I was sure that it was mine, and as I moved out of the flat I argued forcefully enough to win the argument - or at least the knife ${ }^{8}$.

So there may have been no cash nexus - I probably came by the knife by some sort of misappropriation, in which there was no exchange of cash, no shopping, no image of the object prior to me living with it and my choice of it 
was based on my everyday relationship with it. Even if the knife was the one I had bought, it was cheap and would not have required saving, budgeting, credit or loans. The shopping experience had not shaped the knife that I used and liked; I had not been seduced by advertisements or brand names ${ }^{9}$. The act of buying such a knife did in some way symbolise my identity; it was a very early purchase of household equipment linked to leaving my parents' home and learning to cook and fend for myself. But this cannot be grasped by looking at the knife itself, treating it as an image or by considering the shopping context in which it was bought and sold.

The tendency of consumption analysis is to emphasise these features but I wish to argue that to derive the meaning and significance of material culture the mass of objects, such as my kitchen knife, that we live with and use - from the cash nexus is sociologically inadequate. We need to study the complex of social relationships, the 'system of objects', into which such objects as my kitchen knife are fitted. For Baudrillard the system of objects is not concerned with defining them functionally but ". . . instead with the processes whereby people relate to them and with the systems of human behaviour and relationships that result therefrom" (1996: 4). He argues that unlike language or even a technological account of objects, this process is not simply one of classification that needs to be periodically updated, it is constantly being modified and disturbed by the "directly experienced psychological and sociological reality of objects" (Baudrillard 1996: 8). In my story of the knife it is tied to the places where it was lived with and the people that used it - these are the social contexts in which it was (and is!) incorporated into a system of objects. 
One of the key conceptual tools Baudrillard develops is the tension between model $^{10}$ and series, the tension between the personalised, singular characteristics of the object and the cultural system of differences in which it is recognised (1996: 140). To begin with it was the only sharp knife I owned and moved with me in furnished accommodation (l've counted five houses since London) because landlords never provide sharp knives. It was at that point a model - dark wooden handle, stainless blade, sharp point, sharpenable blade - distinctive in the drawer alongside series of plastic handled knives with thin, scalloped but unsharpenable blades. It later became part of a series as other similar knives were acquired - it has five or six companions in the drawer now.

As well as demonstrating ideal characteristics alongside lesser serial objects, the knife has always contributed to what Baudrillard calls 'atmosphere' through being; traditional in style and materials, simple in design, not a gadget, not decorated and visibly functional. The manner of its use is declared in the contrast between the dark warmth of the natural wood of the part to be held and the thin, cold, angled and reflective surfaces of the operational end (Baudrillard 1996: 30-41). At the same time the knife is a 'functional' rather than a ritual or symbolic object, although fitted into a wide range of culinary practices (cutting up meat, salad, fruit, vegetables, in the kitchen, at the diner table, at the picnic) rather than limited to one context or purpose (like the breadknife or fishknife) (Baudrillard 1996: 17-18, 110-112).

The biography of the knife is linked to my biography not only in the geographical moves l've made but also the types of household l've lived in. It has shared the drawer with the knives of landlords, flat sharers, lovers and 
partners. In its early useful life it cut up meat four or five times a week. For the past few years it has not touched meat and seldom sees the inside of a vegetable; it mainly gets to slice a tomato or peel a pear. This is not the sort of biography that Igor Kopytoff (1988) describes, who, having suggested that ownership and use is important, rapidly moves on to talk about arenas of exchange and the revaluation of objects in the cash nexus. But it is a biography that is partly etched on the surface of the knife as a 'patina' of ageing (McCracken 1990: 31-43); the blade is worn and has nicks in it and the handle was, accidentally, prematurely aged in a dishwasher.

The social status of the object arises neither simply from its technical properties, nor from those ascribed to it through the selling process. It arises through the way that humans interact with it, in the context of a system of objects. It is held in a particular way and fits the hand in a certain way, working as a tool, extending the properties of body within what George Mead would call the 'manipulative area' (Mead 1980: 119-139; McCarthy 1984). As an object it enables its user to do certain things and it will be selected for use from amongst other objects with a similar function on the grounds of its properties. As an extension of its user it is not part of direct interaction with other human beings - it has never been used to threaten another human being with violence - but it does enable interaction with other objects, particularly food. Occasionally it gets used to open a stubborn plastic wrapped parcel or for some other domestic use.

The knife also mediates between its user and the other humans who enjoy the food cut up with it. Perhaps more importantly this particular object works as a personal symbolic object that mediates my past to me carrying meanings that 
are inscribed but invisible, like a memento or a photograph (Csikszentmihalyi and Rochberg-Halton 1981; Riggins 1994). I notice that I am more likely than other members of the household to use this knife are. Though not as attractive as more recently acquired knives, for me it feels right; as people say of clothes that they like to wear and be seen in, it is 'comfortable'.

\section{Baudrillard off the hook}

I have argued that Baudrillard both links consumption to the cash nexus and that he provides the source of some themes that I think a sociology of material culture should pursue. However, by the time that the English language writers on consumption to whom l've referred had begun to get caught up in the cash nexus, Baudrillard had of course moved on. Symbolic Exchange and Death (1993 [1976]) marks a turning point in his work in which the issues of consumption have become disconnected from the cash nexus and reconnected to the symbolic economies of sex, death and the simulacrum. Not only is production dead but also, in effect, so is consumption. Why might Baudrillard be able to let go of the cash nexus so easily twenty-two years ago when it has become an increasingly hot topic for English social science? I want to suggest that there are two reasons for this.

Firstly, because the connotations of the word 'consumption' are not quite the same in French as in English, and secondly, because Baudrillard's account of The Consumer Society was a critique of a social form, a stage in the development of capitalism, rather than an account of social practices. In French the verb consommer refers to using, consuming and eating but it also has the positive meanings of accomplishing (as of a task), perpetrating (as of a crime) and consummating (as of a marriage). In English the verb consume 
and the noun form consumption, refer to eating and drinking, being engrossed as well as the negative meanings of using up, expending, destroying or burning up. The standard economic meaning refers to 'expenditure on goods and services for final use' and the noun form also carries the meaning of the wasting away of the body and was a term for tuberculosis (deriving from the Latin word consumptio - wasting away). In English the positive meanings to do with the idea of accomplishment are dealt with by the different word consummate.

The negative meanings of the English word consume are not associated with the French word consommer because there is a separate word in French, consumer which means to wear away, or be eaten up, to destroy, including by fire and, in its reflexive form, se consumer, to waste away. There is also a French noun consomption which has the medical meaning of wasting away, of decline. When Baudrillard uses the term consommation he clearly means the same thing as the writers he refers to - Veblen, Galbraith and others - mean by the word consumption. But there are negative and final connotations in the English use of the word that are dealt with by other words in French. In English this leaves a moral connotation of consumption as wasteful, as a using up, that Veblen connects to pecuniary strength - which is what counts in the cash nexus. In French there is a more sanguine connotation of consommation to do with accomplishment, perhaps even a marriage between person and object.

Secondly, the issue of consumption for Baudrillard is not the consumption of classes of objects or services but the consumption of the code, the system of values and meanings that goes with monetary exchange for goods in the cash 
nexus. In The Consumer Society (1998 [1970]), rather, like Marcuse (1972 [1964]) a few years earlier, Baudrillard mounts a critique of that form of society in which consumption has become the response to affluence, obscuring the cultural hegemony of capitalism that lies behind the mask of individual freedom and choice. To do this he takes on American academia's swallowing of the economistic account of consumption (Galbraith 1967; Riesman 1950; Packard 1960; Boorstein 1963). Baudrillard's critique unpacks the social consequences of the consumption side of the cash nexus, which is so central to the market management of Galbraith's affluent society. So, his critique of advertising is not to focus attention on commodities but to show how it operates as an extension of the mass media as a means of socialising people and distributing knowledge. His comments on 'personalisation' are not to emphasise the choice of the individual but to show that both individuals and the choices they make are a construct of a particular social form. His critique of consumer society grows out of his awareness that the system of objects is, ultimately, ideological and cannot be disconnected from the political dimensions of culture in general (Baudrillard 1996: 153).

Baudrillard's critique points to the central contradiction in consumer society between the desire for consumption and the ethic that rejects wastefulness and excess. It is this dialectic that drives modern culture; the rationality that gives us the technical capacity to produce goods and services that satisfy our every need is the same rationality that when applied to consumption is repulsed by waste and excess, indulgence and greed. Baudrillard's critique of consumer society is not intended to build on his earlier attempt to analyse the system of objects, but to explicate the culture that comes with the shift to 
consumption in affluent society. It is precisely around the cash nexus that culture is dragged down to what he calls, almost echoing Marcuse's argument about the repressive desublimation effect of one-dimensional culture (1964: 57-77), the 'lowest common culture' (Baudrillard 1998: 104).

\section{Conclusions}

For Westergaard the cash nexus was brittle; if it broke then the allegiance of workers to the system would disappear. But politics is always more complex than the single strand of the cash nexus, even when the workers are privatised, affluent and instrumental. Such workers became the consumers of the consumer society, enjoying the purchase of a range of objects and services that improved the quality of their lives; cars, washing machines, televisions, furniture, clothes, holidays, insurance and leisure.

The cash nexus did break for those who lost their jobs, often whole communities and industries, but for those of us who continue to have incomes it enables us to partake in the life of society. This does not mean that consumption is an end in itself for the vast majority of people. The cash nexus of consumption is just the beginning of a 'quasi-social' relationship with what was bought. These relations with objects are a key part of what binds us to the social order and such relationships occur whether or not cash was exchanged. The objects of material culture may be acquired by inheritance, through sharing, as a gift, by finding, by misappropriation as well as by buying. In late capitalism they are more likely to follow from the handing over of money but it is not the handing over of cash or the inducements to do so that determines the way objects are lived with or used. 
So how should material culture be approached by sociology? I have been arguing that rather than understand the relationship with material objects as derived from the process of purchase, it should be seen as more akin to the relationships between people. The reason for arguing for this 'quasi-social' relationship is for two reasons, both of enormous sociological importance. The first is that objects become vehicles of meaning. This is not just in a simple sense of the object having a symbolic meaning which is available to be decoded (handbag = mature woman) but allows for layers of both cultural and personal meaning to be embedded in the object. For example the materials and the techniques of manufacture of a handbag will indicate much about the technological state of the culture that produces it. The design (size, shape, colour, fixings, handles) will orient the object to the cultural code of fashion which in turn relates in a non-determinative way to individual identity (Simmel 1971). These meanings are not fixed because the material culture in which the object exists change around it long after it is bought; a handbag style may come back into fashion, the development of new production techniques may distinguish the handbag as of a different era. Perhaps most importantly, the object ages and often it ages with its possessor so that the meanings of particular life experiences become linked to the object. Peoples' quasi-social relationships with objects then attach them to their culture and their social life, linking past and present, mediating direct human relationships and indirect cultural ones.

The second reason for thinking of the relationship with objects as 'quasisocial' is that human beings interact with the object. The use of the object touching, looking, placing, carrying, incorporating it into activities, cleaning 
and maintaining it - integrates the object into social lives. Objects (such as the knife in my story, or a woman's handbag) enable people to do what they do in the particular social context in which they live. It is possible to imagine humans living, as most other animals do, without the aid of objects that they have made, but human societies are distinguished by the particular sets of objects that are used to carry on life. It is this fact that is the cornerstone of archaeology and central to anthropology but strangely absent from sociology.

These two reasons are of course interconnected; it is through interaction with objects that their meanings become disembedded and given a context. While objects are functional (cutting up food, carrying personal possessions) they are at the same time situating the people who use them in social and historical contexts. I have been arguing that the focus on consumption in contemporary English writing has tended to divert attention away from the more routine relationships with objects. Some American writing has in contrast drawn on phenomenology, symbolic interactionism and ethnography to link the meanings of objects to the uses they have and the way they are lived with (e.g. Csikszentmihalyi and Rochberg-Halton 1981; Riggins 1994a). There are of course traces of this approach in the consumption literature. Lury discusses the connection between things and social lives (1996: 10-26), Slater has a chapter on the 'uses of things' (1997: 148-173) and Miller offers the tantalising idea of 'sublation' as a sort of de-alienation relationship with objects that occurs as we use and live with them:

\footnotetext{
The authenticity of artifacts as culture derives ... from their active participation in a process of social self-creation in which they are directly constitutive of our understanding of ourselves and others. The
} 
key criteria for judging the utility of contemporary objects is the degree to which they may or may not be appropriated from the forces which created them, which are mainly of necessity, alienating.

(Miller 1987: 215)

However, it is studies of consumption and the seemingly dominating feature of the cash nexus that attract research interest rather than the more mundane, though difficult to study, topic of 'objects in use'. There are difficulties with studying the 'taken-for-granted' rather than the socially hot topic of 'what-tobuy?' People do not think about their relationships with objects much, especially when those objects are doing what is required of them. Research techniques that observe things in use and find ways of asking people about how they live with them, are necessary for a sociology of things ${ }^{11}$. Such techniques are emerging in the context of studies of work (e.g. Heath and Hindmarsh, forthcoming), the sociology of technology and the ethnography of contemporary, everyday life ${ }^{12}$.

As with the impact of affluence on the world of work, the impact of affluence on the social world of material culture should not be seen as determined by the cash nexus. I have argued that material culture should be recognised as complex and interesting in itself and suggested that Baudrillard's idea of a system of objects would provide a firmer foundation for an empirical 'sociology of things' than the cash nexus. In place of the current focus on consumption, studies of the 'quasi-social' relationships of meaning and interaction between humans and objects are needed. The relationships between people, cultures and the things they live with and use have existed as long as societies have; they extend much further than the relations of consumption . 
${ }^{1}$ Runciman 1966; MacKenzie and Silver 1968; Goldthorpe et al. 1968.

${ }^{2}$ Although in the Manifesto of the Communist Party Marx and Engels do not make reference to Carlyle, elsewhere when they write about cash payments as constituting a social nexus they do. For example, this is how Engels describes the bourgeois attitude to the working class: "It lies quite outside the comprehension of the middle classes that there should be any relationship between masters and men other than the purely economic link. The bourgeoisie see in the workers only 'hands' and calls them 'hands' to their faces. As Carlyle says, the middle classes can conceive of no relationship between human beings than the cash nexus." (Engels 1958 [1845]: 312).

Carlyle introduced the phrase in the context of discussing the changing social order from one in which the aristocracy governed the lower classes: "For, in one word, Cash Payment had not then grown to be the universal sole nexus of man to man; it was something other than money that the high then expected from the low, and could not live without getting from the low. Not as buyer and seller alone, of land or what else it might be, but in many senses still as soldier and captain, as clansman and head, as loyal subject and guiding king, was the low related to the high. With the supreme triumph of Cash, a changed time has entered; there must a changed Aristocracy enter." (Carlyle 1971 [1839]: 213-4). Carlyle, Marx and Engels and Westergaard use the phrase the 'cash nexus' to point to the way the simple economic relation of cash displaces and replaces the complex and enduring social relations of other social formations.

${ }^{3}$ See for example Runciman 1966: 208-218.

${ }^{4}$ Although of course his For a Critique of the Political Economy of the Sign was published in English translation 1981 and a large chunk of La Société de Consommation was published in Selected Writings in 1988 and another large chunk in Revenge of the Crystal in 1990. I guess a number of commentators were reading and using Baudrillard's ideas directly from the French (perhaps most importantly Marshall Sahlins in Culture and Practical Reason in 1979) although the reading of work in foreign languages is more typical of the American and European academic than of the English. 
${ }^{5}$ Peter Saunders has even argued that there is something intrinsically human in the desire to buy one's own home (1990). He uses both sociobiological arguments about desire for possession and an account of the development of a particularly English material culture to explain the dominant choice for home possession as 'ownership'.

${ }^{6}$ I have developed these themes are more length elsewhere; Dant 1999.

${ }^{7}$ As Barthes points out, the use of the first person in such writing should be understood as imaginary, in the psychoanalytic sense of the term: "Writing is precisely that space in which the persons of grammar and the origins of discourse mingle, combine, and lose each other until they are unidentifiable: writing is the truth not of the person (of the author), but of language." (Barthes 1988 [1974]: 8)

${ }^{8}$ I can, with hindsight, admit that my rhetoric was somewhat motivated by the disturbance of the beer-drinking, blues-listening household l'd shared with her lover before she moved in.

${ }^{9}$ There was no brand name on the handle or any label or packaging with the knife. However, in the 1980 s I realised that the blade itself carries the brand name 'Sabatier' - by then such things had become important - even though it did not look like the Sabatier knives being marketed at that time.

${ }^{10}$ The word 'model' has almost contradictory meanings; both as a representation, usually smaller, derived from a series and as the pattern or standard to be imitated by the series. Baudrillard's account seems to exploit this ambiguity, in which the singularity of the model is cultural rather than material. The model can of course refer to a series of objects that are similar in form and function - like a model of car - while personalisation can 'modelise' one of the series through colour, optional extras and other distinguishing features (Baudrillard 1996: 137-155).

${ }^{11}$ In arguing against an array of cultural critics and commentators on consumption, the authors of The Story of the Sony Walkman stress ". . . the importance of exploring the different uses made of the Walkman in the practices of their everyday lives by different sorts of people in 
different contexts" (du Gay et al. 1997:94). But all they can draw on are Sony's own marketing studies which they have been lucky enough to get some access to.

${ }^{12}$ e.g. Miller's own study of kitchens (Miller 1988), Corrigan's (1994) of clothes as lived with objects and Riggins's (1994a) of his parents' living room'. Other examples include contributions by Chevalier, Pellegram, and Jarman in Miller 1998b, and contributions by Danet and Katriel, Shields, Callum-Swan and Manning, in Riggins 1994b. See also de Certeau et al. 1994. 


\section{Bibliography}

Barthes, R. 1988. The Semiotic Challenge, Oxford: Blackwell.

Baudrillard, J. 1981. For a Critique of the Political Economy of the Sign, [no place of publication]: Telos Press.

Baudrillard, J. 1988. Selected Writings, edited by Mark Poster, Cambridge: Polity Press.

Baudrillard, J. 1990. Revenge of the Crystal: Selected Writings on the Modern Object and its Destiny, 1968-1983, London: Pluto Press.

Baudrillard, J. 1993 [1976]. Symbolic Exchange and Death, London: Sage.

Baudrillard, J. 1996 [1968]. The System of Objects, London: Verso.

Baudrillard, J. 1998 [1970]. The Consumer Society, London: Sage.

Bocock, R. 1993. Consumption, London: Routledge.

Boorstein, D. 1963. The Image, or What Happened to the American Dream, Harmondsworth: Penguin.

Carlyle, Thomas, 1971 [1839]. "Chartism" in Selected Writings, Harmondsworth: Penguin.

de Certeau, M.; Giard, L.; Mayol, P. (1994) L'invention du quotidien 2. Habiter, cuisiner, Paris: Éditions Gallimard.

Corrigan, P. 1994. "Interpreted, circulating, interpreting: Three dimensions of the clothing object" in S. H. Riggins (ed.) The Socialness of Things: Essays on the Socio-Semiotics of Objects, New York: Mouton de Gruyter.

Corrigan, P. 1997. The Sociology of Consumption, London: Sage.

Csikszentmihalyi, M. and Rochberg-Halton, E. 1981. The Meaning of Things: Domestic symbols and the self, Cambridge: Cambridge University Press.

Dant, T. 1999. Material Culture in the Social World: Values, Activities, Lifestyles, Buckingham: Open University Press.

Engels, Frederick, 1958 [1845]. The Condition of the Working Class in England, Oxford: Basil Blackwell.

Ewen, Stuart and Ewen, Elizabeth, 1992. Channels of Desire: Mass Images and the Shaping of American Consiousness, Minneapolis: University of Minnesota Press.

Falk, Pasi and Campbell, Colin, (eds), 1997. The Shopping Experience, London: Sage.

Gabriel, Y. and Lang, T. (1995) The Unmanageable Consumer: Contemporary Consumption and its Fragmentation, London: Sage.

du Gay, P., Hall, S., Janes, L., Mackay, H., Negus, K. 1997. Doing cultural studies: the story of the Sony Walkman, London: Sage.

Galbraith, J. K. 1958 [1962]. The Affluent Society, Harmondsworth: Penguin Books.

Goldthorpe, J. H. Lockwood, D., Bechhofer, F. and Platt, J. 1968. The Affluent Worker: (1) Industrial Attitudes and Behaviour and (2) Political Attitudes and Behaviour, Cambridge: Cambridge University Press. 
Goldthorpe, J. H., Lockwood, D., Bechhofer, F. and Platt, J. 1969. The Aflluent Worker in the Class Structure, Cambridge: Cambridge University Press.

Haug, W.F. 1986. Critique of Commodity Aesthetics: Appearance, Sexuality and Advertising in Capitalist Society, Cambridge: Polity Press.

Heath, C.C. and Hindmarsh, J. (forthcoming) "Objects in action: The occasioned sense of the material environment", Social Psychological Quarterly

Jhally, Sut, 1987. The Codes of Advertising: Fetishism and the Political Economy of Meaning in the Consumer Society, London: Routledge.

Kopytoff, Igor, 1986. "The cultural biography of things" in A. Appadurai (ed.) The Social Life of Things: Commodities in Cultural Perspective, Cambridge: Cambridge University Press.

Leiss, William, 1978. The Limits to Satisfaction: On Needs and Commodities, London: Marion Boyars.

Lury, C. 1996. Consumer Culture, Cambridge: Polity.

Marcuse, H. 1972 [1964]. One-Dimensional Man, London: Abacus.

Marx, K. and Engels, F. 1968 [1872]. "Manifesto of the Communist Party" in Selected Works in One Volume, London: Lawrence and Wishart.

McCarthy, E. D. 1984. "Toward a Sociology of the Physical World George Herbert Mead on Physical Objects", Studies in Symbolic Interaction, 5: 105121.

McCracken, G. 1990. Culture and Consumption: New Approaches to the Symbolic Character of Consumer Goods and Activities, Bloomington, Indiana: Indiana University Press.

McKenzie, R. and Silver, A. 1968. Angels in Marble: Working Class Conservatives in Urban England, London: Heinemann.

Mead, G. H. 1980 [1932]. Philosophy of the Present, Chicago: University of Chicago Press.

Miles, Steven, 1998. Consumerism - as a way of life, London: Sage.

Miller, D. 1987. Material Culture and Mass Consumption, Oxford: Blackwell.

Miller, D. 1988. "Appropriating the state on the council estate", Man, Vol. 23: 353372.

Miller, D. 1995. "Consumption as the Vanguard of History" in D. Miller ed. Acknowledging Consumption, London: Routledge.

Miller, D. 1998a. A Theory of Shopping, Cambridge: Polity Press.

Miller, D. 1998. (ed.) Material Cultures, London: UCL Press.

Miller, D., Jackson, P., Thrift, N., Holbrook, J., Rowlands, M. 1998. Shopping, Place and Identity, London: Routledge.

Packard, V. 1960 [1950]. The Hidden Persuaders, Harmondsworth: Penguin.

Riesman, D. (with N. Glazer and R. Denny) 1950. The Lonely Crowd: A Study of the Changing American Character, New Haven: Yale University Press.

Riggins, S. H. 1994a. "Fieldwork in the living room" in S. H. Riggins (ed.) The Socialness of Things: Essays on the Socio-Semiotics of Objects, New York: Mouton de Gruyter. 
Riggins, S. H. 1994b. (ed.) The Socialness of Things: Essays on the Socio-Semiotics of Objects, New York: Mouton de Gruyter.

Runciman, W. G. 1966. Relative deprivation and social justice: A study of attitudes to social inequality in twentieth-century England, London: Routledge and Kegan Paul.

Sahlins, M. 1976. Culture and Practical Reason, Chicago: University of Chicago Press.

Saunders, P. 1990, A Nation of Home Owners, London: Unwin Hyman.

Shields, R. 1992. Lifestyle Shopping: The Subject of Consumption, London: Routledge.

Simmel, G. (1971 [1904]) "Fashion" in O. Levine (ed.) Georg Simmel: On Individuality and Social Forms, London: University of Chicago Press.

Slater, D. 1997. Consumer Culture and Modernity, Cambridge: Polity Press.

Westergaard, J. H. 1970. "The Rediscovery of the Cash Nexus", The Socialist Register 1970, London: The Merlin Press.

Westergaard, J. H. and Resler, H. 1975. Class in a capitalist society: a study of contemporary Britain, London : Heinemann Educational.

Campbell, C. 1987. The Romantic Ethic and the Spirit of Modern Consumerism, Oxford: Blackwell.

*Lury, C. 1996. Consumer Culture, Cambridge: Polity Press.

Lunt, P. and Livingstone, S. 1992. Mass Consumption and Personal Identity, Buckingham: Open University Press.

Dittmar, H. 1992. The Social Psychology of Material Possessions: To Have Is To Be, Hemel Hempstead, Herts.: Harvester Wheatsheaf.

*Douglas, M. and Isherwood, B. (1996 [1979]) The World of Goods: Towards and Anthropology of Consumption, London: Routledge.

Appadurai, A. ed. 1986. The Social Life of Things: Commodities in cultural perspective, Cambridge: Cambridge University Press.

Featherstone, M. 1991. Consumer Culture and Postmodernism, London: Sage.

*Slater, D. 1997. Consumer Culture and Modernity, Cambridge: Polity Press.

*Falk, P. and Campbell, C. eds. 1997. The Shopping Experience, London: Sage.

*Kopytoff, I. 1986. "The cultural biography of things" in A. Appadurai (ed.) The Social Life of Things: Commodities in Cultural Perspective, Cambridge: Cambridge University Press.

Galbraith, J. K. 1967. The New Industrial State, New York: Signet. 